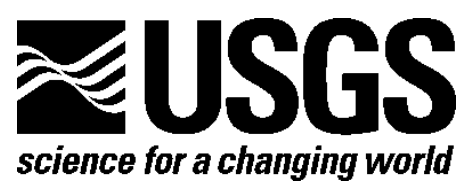

\title{
Input-Form Data for the U.S. Geological Survey Assessment of the Mississippian Barnett Shale of the Bend Arch-Fort Worth Basin Province, 2015
}

By Kristen R. Marra, Ronald R. Charpentier, Christopher J. Schenk, Michael D. Lewan, Heidi M. LeathersMiller, Timothy R. Klett, Stephanie B. Gaswirth, Phuong A. Le, Tracey J. Mercier, Janet K. Pitman, and Marilyn E. Tennyson

Open-File Report 2016-1097

U.S. Department of the Interior U.S. Geological Survey 


\section{U.S. Department of the Interior \\ SALLY JEWELL, Secretary}

\section{U.S. Geological Survey \\ Suzette M. Kimball, Director}

U.S. Geological Survey, Reston, Virginia: 2016

For more information on the USGS-the Federal source for science about the Earth,

its natural and living resources, natural hazards, and the environment-visit

http://store.usgs.gov or call 1-888-ASK-USGS (1-888-275-8747).

For an overview of USGS information products, including maps, imagery, and publications, visit http://www.usgs.gov/pubprod/.

Any use of trade, firm, or product names is for descriptive purposes only and does not imply endorsement by the U.S. Government.

Although this information product, for the most part, is in the public domain, it also may contain copyrighted materials as noted in the text. Permission to reproduce copyrighted items must be secured from the copyright owner.

Suggested citation:

Marra, K.R., Charpentier, R.R., Schenk, C.J., Lewan, M.D., Leathers-Miller, H.M., Klett, T.R., Gaswirth, S.B., Le, P.A., Mercier, T.J., Pitman, J.K., and Tennyson, M.E., 2016, Input-form data for the U.S.

Geological Survey assessment of the Mississippian Barnett Shale of the Bend Arch-Fort Worth Basin Province, 2015: U.S. Geological Survey Open-File Report 2016-1097, 31 p.,

http://dx.doi.org/10.3133/ofr20161097.

ISSN 2331-1258 (online) 


\section{Contents}

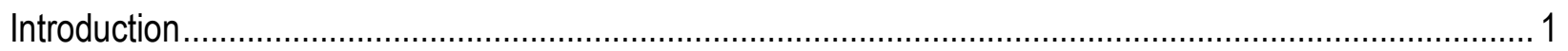

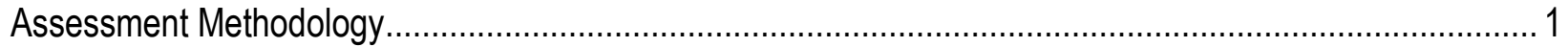

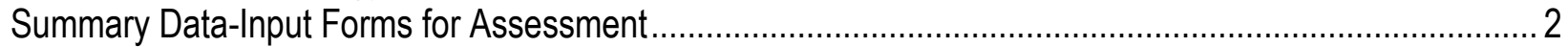

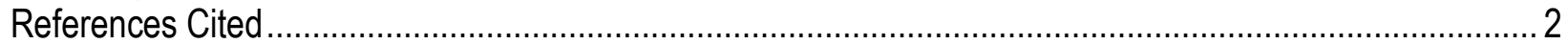

\section{Tables}

1. Input parameters for the Barnett Continuous Gas Assessment Unit (50450161), Bend Arch-Fort Worth Basin Province

2. Input parameters for the Barnett Mixed Continuous Gas and Oil Assessment Unit (50450162), Bend Arch-Fort Worth Basin Province 


\section{Input-Form Data for the U.S. Geological Survey Assessment of the Mississippian Barnett Shale of the Bend Arch-Fort Worth Basin Province, 2015}

By Kristen R. Marra, Ronald R. Charpentier, Christopher J. Schenk, Michael D. Lewan, Heidi M. LeathersMiller, Timothy R. Klett, Stephanie B. Gaswirth, Phuong A. Le, Tracey J. Mercier, Janet K. Pitman, and Marilyn E. Tennyson

\section{Introduction}

In 2015, the U.S. Geological Survey (USGS) released an updated assessment of undiscovered, technically recoverable shale gas and shale oil resources of the Mississippian Barnett Shale in north-central Texas (Marra and others, 2015). The Barnett Shale was assessed using the standard continuous (unconventional) methodology established by the USGS for two assessment units (AUs): (1) Barnett Continuous Gas AU, and (2) Barnett Mixed Continuous Gas and Oil AU. A third assessment unit, the Western Barnett Continuous Oil AU, was also defined but was not quantitatively assessed because of limited data within the extent of the AU. The purpose of this report is to provide supplemental documentation of the quantitative input parameters applied in the Barnett Shale assessment.

\section{Assessment Methodology}

The USGS uses two distinct peer-reviewed methodologies to assess for conventional and continuous resource accumulations. While both methodologies result in probabilistic estimates of undiscovered petroleum resources, each require specific input parameters. Conventional resources are defined where oil or natural gas is buoyant upon water and where petroleum resources have migrated into structural and (or) stratigraphic traps. The primary input data are related to the numbers and sizes of undiscovered conventional accumulations (Klett and others, 2005). In contrast, a continuous resource accumulation is defined as oil and (or) natural gas that has been generated from a thermally mature source rock and has remained within or adjacent to the source rock. The continuous resource assessment methodology is primarily focused on the uncertainties regarding the average drainage area of wells and the average estimated ultimate recoveries (EURs) of wells, as well as the projection of future success ratios (Charpentier and Cook, 2012). These methodologies are summarized in more detail in multiple published reports (Klett and Charpentier, 2003; Crovelli, 2005; Klett and Schmoker, 2005; Klett and others, 2005; Schmoker, 2005; Schmoker and Klett, 2005; Charpentier and Cook, 2012).

For the Barnett Shale assessment, the statistically based summary input data form for continuous resources was used for both quantitatively assessed AUs to document the descriptive information used in the resource calculation for each defined assessment unit (Charpentier and Cook, 2012). For the Barnett Mixed Continuous Oil and Gas AU, a modification was made to 
the continuous input data form for "sweet spot" areas to incorporate both oil and gas production within the AU (line 4 on the form), as the assessment unit type was characterized as both gas and oil. A "sweet spot" is generally defined as an area with favorable geologic characteristics for petroleum resource production, including an adequate thermal history, gas content, and matrix rock properties. In this case, the percentage of untested assessment-unit area in sweet spots (given in percent) was modified to represent the percent of undrilled wells that could potentially be oil wells (also given in percent). Subsequently, the section for estimated ultimate recovery distributions per well in sweet spot areas (lines 5a and 5b) and nonsweet spot areas (lines 6a and 6b) was changed to reflect the future success ratio and average EUR distributions for oil wells and for gas wells, respectively. In addition, data for the coproduct ratios and ancillary data section were provided for both oil and gas wells.

\section{Summary Data-Input Forms for Assessment}

The data-input forms for the two quantitatively assessed Barnett Shale AUs are provided in tables 1 and 2.

\section{References Cited}

Charpentier, R.R., and Cook, T.A., 2012, Improved USGS methodology for assessing continuous petroleum resources, version 2.0: U.S. Geological Survey Data Series 547, 22 p.

Crovelli, R.A., 2005, Analytical resource method for continuous petroleum accumulations-The ACCESS assessment methodology, chap. 22 of USGS Southwestern Wyoming Province Assessment Team, Petroleum systems and geologic assessment of the Southwestern Wyoming Province, Wyoming, Colorado, and Utah: U.S. Geological Survey Digital Data Series DDS69-B, 10 p.

Klett, T.R., and Charpentier, R.R., 2003, FORSPAN Model users guide: U.S. Geological Survey Open-File Report 2003-354, 37 p.

Klett, T.R., and Schmoker, J.W., 2005, Input-data form and operational procedure for the assessment of continuous accumulations, 2002, chap. 18 of USGS Southwestern Wyoming Province Assessment Team, Petroleum systems and geologic assessment of the Southwestern Wyoming Province, Wyoming, Colorado, and Utah: U.S. Geological Survey Digital Data Series DDS-69-D, 8 p.

Klett, T.R., Schmoker, J.W., and Charpentier, R.R., 2005, U.S. Geological Survey input-data form and operational procedure for the assessment of conventional petroleum accumulations, chap. 20 of USGS Southwestern Wyoming Province Assessment Team, Petroleum systems and geologic assessment of the Southwestern Wyoming Province, Wyoming, Colorado, and Utah: U.S. Geological Survey Digital Data Series DDS-69-D, 7 p.

Marra, K.R., Charpentier, R.R., Schenk, C.J., Lewan, M.D., Leathers-Miller, H.M., Klett, T.R., Gaswirth, S.B., Le, P.A., Mercier, T.J., Pitman, J.K., and Tennyson, M.E., 2015, Assessment of undiscovered shale gas and shale oil resources in the Mississippian Barnett Shale, Bend Arch-Fort Worth Basin Province, north-central Texas: U.S. Geological Survey Fact Sheet 2015-3078, 2 p.

Schmoker, J.W., 2005, U.S. Geological Survey assessment concepts for continuous petroleum accumulations, chap. 13 of USGS Southwestern Wyoming Province Assessment Team, Petroleum systems and geologic assessment of the Southwestern Wyoming Province, Wyoming, Colorado, and Utah: U.S. Geological Survey Data Series DDS-69-D, 7 p. 
Schmoker, J.W., and Klett, T.R., 2005, U.S. Geological Survey assessment concepts for conventional petroleum accumulations, chap. 19 of USGS Southwestern Wyoming Province Assessment Team, Petroleum systems and geologic assessment of the Southwestern Wyoming Province, Wyoming, Colorado, and Utah: U.S. Geological Survey Data Series DDS-69-D, 6 p.

ISSN 2331-1258 (online)

http://dx.doi.org/10.3133/ofr20161097 
Table 1. (following 13 pages) Input parameters for the Barnett Continuous Gas Assessment Unit (50450161), Bend Arch-Fort Worth Basin Province. [bcfg, billion cubic feet of gas; mmcfg, million cubic feet of gas, cfg, cubic feet of gas; mmbo, million barrels of oil; bo, barrel of oil, bliq, barrel of liquid; bngl, barrel of natural gas liquids; $m$, meters; $A U$, assessment unit; EUR, estimated ultimate recovery] 
USGS U.S. PETROLEUM RESOURCES ASSESSMENT

INPUT DATA FORM FOR CONTINUOUS ACCUMULATIONS (version 1.3, April 29, 2015)

IDENTIFICATION INFORMATION

\begin{tabular}{|c|c|c|c|}
\hline Assessment Geologist: & K.R. Marra & Date: & $8 / 26 / 2015$ \\
\hline Region: & North America & \multirow{5}{*}{$\begin{array}{l}\text { Number: } \\
\text { Number: } \\
\text { Number: } \\
\text { Number: }\end{array}$} & 5 \\
\hline Province: & Bend Arch-Fort Worth Basin & & 5045 \\
\hline Total Petroleum System: & Barnett-Paleozoic & & 504501 \\
\hline Assessment Unit: & Barnett Continuous Gas & & 50450161 \\
\hline Based on Data as of: & IHS (2015) & & \\
\hline Notes from Assessor: & & & \\
\hline
\end{tabular}

\section{CHARACTERISTICS OF ASSESSMENT UNIT}

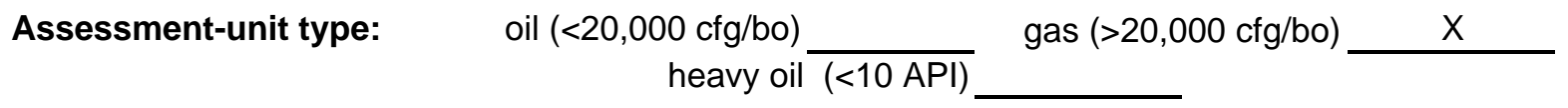

Well type:

Major reservoir type (Choose one.):

vertical horizontal

shale $\quad \mathrm{X}$
coal $\quad \begin{array}{r}\text { low-permeability clastics } \\ \text { low-permeability carbonates } \\ \text { diatomite }\end{array}$

Minimum EUR per well $\quad 0.02$ (mmbo for oil AU; bcfg for gas AU)

Number of tested wells: 18,922

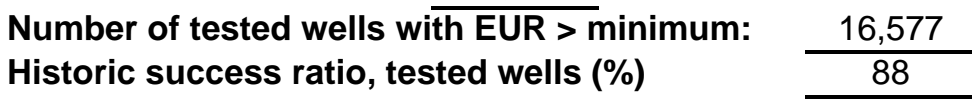

Assessment-Unit Probability:

What is the probability that at least one well within the AU will have

production capacity of at least the minimum EUR?

\section{NUMBER OF UNDRILLED WELLS WITH POTENTIAL FOR ADDITIONS TO RESERVES}

1. Productive area of accumulation (acres): (triangular)

calculated mean $\underline{6,473,000}$ minimum $\underline{6,000,000}$ mode $\underline{6,419,000}$ maximum $\underline{7,000,000}$

2. Uncertainty about average drainage area of wells (acres): (triangular)

calculated mean $100 \quad$ minimum $\quad 60 \quad$ mode $\quad 100 \quad$ maximum 140

3. Percentage of total assessment-unit area that is untested (\%): (triangular)

calculated mean $73 \quad$ minimum $\quad 65 \quad$ mode $\quad 73 \quad$ maximum $\quad 80$

4. Percentage of untested assessment-unit area in sweet spots (\%): (triangular)

calculated mean $\quad 28 \quad$ minimum $\quad 15 \quad$ mode $\quad 30 \quad$ maximum $\quad 40$ 


\section{ESTIMATED ULTIMATE RECOVERY (EUR) PER WELL \\ SWEET SPOTS}

5a. Future success ratio (\%): (triangular)

calculated mean 89

minimum

85

mode

90

maximum

92

5b. Uncertainty about average EUR (mmbo for oil; bcfg for gas): (shifted truncated lognormal)

calculated mean $\quad 2.034$

minimum

1

median

2

maximum

3

\section{NON-SWEET SPOTS}

6a. Future success ratio (\%): (triangular)

calculated mean 73

minimum

60

mode

75

maximum

85

6b. Uncertainty about average EUR (mmbo for oil; bcfg for gas): (shifted truncated lognormal)

calculated mean $\quad 0.956$

minimum

0.5

median

0.9

maximum

2

\section{UNCERTAINTY ABOUT AVERAGE COPRODUCT RATIOS FOR UNTESTED WELLS}

(triangular)

Oil assessment unit:

Gas/oil ratio (cfg/bo)

minimum

mode

maximum

NGL/gas ratio (bngl/mmcfg)

Gas assessment unit:

Liquids/gas ratio (bliq/mmcfg)

0.5

1.3

2 


\section{SELECTED ANCILLARY DATA FOR UNTESTED WELLS}

(no specified distribution type)

Oil assessment unit: API gravity of oil (degrees)

Sulfur content of oil (\%)

Depth $(\mathrm{m})$ of water (if applicable)

Drilling depth $(\mathrm{m})$

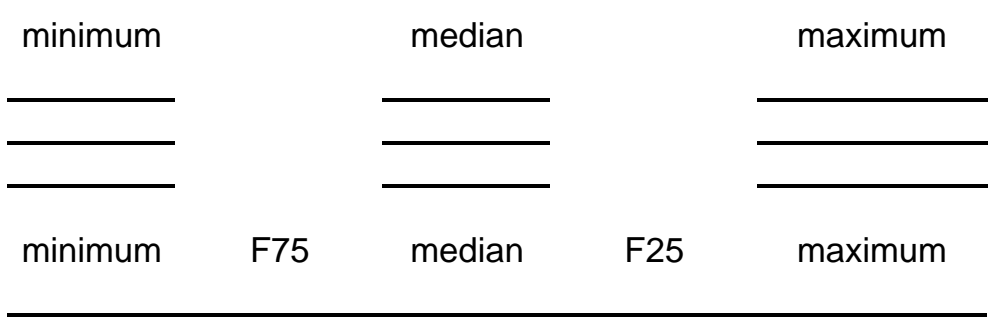

\begin{tabular}{|c|c|c|c|c|}
\hline $\begin{array}{c}\text { minimum } \\
0.50\end{array}$ & & $\begin{array}{c}\text { median } \\
2.50\end{array}$ & & $\begin{array}{c}\text { maximum } \\
20.00\end{array}$ \\
\hline 0.10 & & 1.00 & & 5.00 \\
\hline 0.00 & & 0.00 & & 0.00 \\
\hline $\begin{array}{l}\text { minimum } \\
700\end{array}$ & F75 & $\begin{array}{c}\text { median } \\
1900\end{array}$ & $\mathrm{~F} 25$ & $\begin{array}{c}\text { maximum } \\
3000\end{array}$ \\
\hline
\end{tabular}

Gas assessment unit: Inert-gas content (\%)

$\mathrm{CO}_{2}$ content (\%)

Hydrogen sulfide content (\%)

Heating value (BTU)

Depth $(\mathrm{m})$ of water (if applicable)

Drilling depth $(m)$

\begin{tabular}{c}
$\frac{\frac{\text { conventional }}{1}}{\mathrm{frac}}$ \\
\hline 0.72 \\
\hline
\end{tabular}

0.72

\section{Completion practices:}

1. Typical well-completion practices (conventional, open hole, open cavity, other)

2. Fraction of wells drilled that are typically stimulated

3. Predominant type of stimulation (none, frac, acid, other)

4. Historic fraction of wells drilled that are horizontal 


\section{ALLOCATIONS OF POTENTIAL ADDITIONS TO RESERVES TO STATES Surface Allocations}

1. Texas

$\begin{array}{ll}\text { Onshore: } & \frac{100}{100} \text { area } \% \text { of the } A U \\ \text { mean volume } \% \text { of the } A U & \text { affshore: } \quad \begin{array}{l}\text { area } \% \text { of the } A U \\ \text { mean volume } \% \text { of the } A U\end{array}\end{array}$

2.

Onshore: area $\%$ of the $\mathrm{AU}$ mean volume $\%$ of the $A U$

Offshore: area $\%$ of the $\mathrm{AU}$ mean volume $\%$ of the $\mathrm{AU}$

3.

Onshore:

Offshore:

Onshore:

Offshore:

Onshore:

Offshore: area $\%$ of the $\mathrm{AU}$ mean volume $\%$ of the $A U$ area $\%$ of the $\mathrm{AU}$ mean volume $\%$ of the $A U$

5. mean volume $\%$ of the $A U$ area $\%$ of the $\mathrm{AU}$ mean volume $\%$ of the $A U$ 


\section{ALLOCATIONS OF POTENTIAL ADDITIONS TO RESERVES TO STATES} (continued)

6. area $\%$ of the $\mathrm{AU}$ mean volume $\%$ of the $\mathrm{AU}$

Offshore: area $\%$ of the $\mathrm{AU}$ mean volume $\%$ of the $A U$

7.

Onshore:

area $\%$ of the $\mathrm{AU}$

mean volume $\%$ of the $A U$

Offshore: area $\%$ of the $\mathrm{AU}$ mean volume $\%$ of the $A U$

8.

Onshore:

Offshore: area $\%$ of the $A U$ mean volume $\%$ of the $A U$ area $\%$ of the $\mathrm{AU}$ mean volume $\%$ of the $A U$

9.

Onshore: area $\%$ of the $\mathrm{AU}$ mean volume $\%$ of the $A U$

Offshore: area $\%$ of the $\mathrm{AU}$ mean volume $\%$ of the $A U$

10.

Onshore: area $\%$ of the $A U$ mean volume $\%$ of the $A U$

Offshore: area $\%$ of the $\mathrm{AU}$ mean volume $\%$ of the $A U$ 


\section{ALLOCATIONS OF POTENTIAL ADDITIONS TO RESERVES TO PROVINCES Surface Allocations}

1. Number: 5045

Onshore:

Offshore:

2. Number: 5049

Onshore:

Offshore:

3. Number:

4. Number:

Onshore:

Offshore:

5. Number:

Onshore:

Offshore:
Name: Bend Arch-Forth Worth Basin

99.62 area \% of the AU

100.00 mean volume $\%$ of the $\mathrm{AU}$

area $\%$ of the $\mathrm{AU}$

mean volume $\%$ of the $A U$

Name: Gulf Coast Mesozoic

0.38 area $\%$ of the $\mathrm{AU}$

0.00 mean volume $\%$ of the $\mathrm{AU}$

area $\%$ of the $\mathrm{AU}$

mean volume $\%$ of the $A U$

Name:

area $\%$ of the $\mathrm{AU}$

mean volume $\%$ of the $A U$

area $\%$ of the $\mathrm{AU}$

mean volume $\%$ of the $A U$

Name:

area $\%$ of the $\mathrm{AU}$

mean volume $\%$ of the $\mathrm{AU}$

area $\%$ of the $\mathrm{AU}$

mean volume $\%$ of the $A U$

Name:

area $\%$ of the $\mathrm{AU}$

mean volume $\%$ of the $\mathrm{AU}$

area $\%$ of the $\mathrm{AU}$

mean volume $\%$ of the $A U$ 


\section{ALLOCATIONS OF POTENTIAL ADDITIONS TO RESERVES TO PROVINCES}

(continued)

6. Number:

Name:

Onshore:

Offshore:

area $\%$ of the AU

mean volume $\%$ of the $\mathrm{AU}$

mean volume $\%$ of the $\mathrm{AU}$
area $\%$ of the $\mathrm{AU}$
mean volume $\%$ of the $\mathrm{AU}$

7. Number:

Name:

Onshore:

area $\%$ of the $A U$

mean volume $\%$ of the $\mathrm{AU}$

Offshore:

area $\%$ of the $\mathrm{AU}$

mean volume $\%$ of the $\mathrm{AU}$

8. Number:

Name:

Onshore:

area $\%$ of the $A U$

mean volume $\%$ of the $A U$

Offshore:

area $\%$ of the $\mathrm{AU}$

mean volume $\%$ of the $A U$

9. Number:

Name:

Onshore:

area $\%$ of the $\mathrm{AU}$

mean volume $\%$ of the $A U$

Offshore:

area $\%$ of the $\mathrm{AU}$

mean volume $\%$ of the $A U$

10. Number:

Name:

Onshore:

area $\%$ of the $\mathrm{AU}$

mean volume $\%$ of the $A U$

Offshore:

area \% of the $\mathrm{AU}$

mean volume $\%$ of the $A U$ 


\section{ALLOCATIONS OF POTENTIAL ADDITIONS TO RESERVES TO GENERAL LAND OWNERSHIPS Surface Allocations}

1. Federal Lands mean VOLUME \% in entity

2. Private Lands mean VOLUME \% in entity

3. Tribal Lands mean VOLUME \% in entity

4. Other Lands mean VOLUME \% in entity

5. Texas State Lands mean VOLUME \% in entity 0.17

6. mean VOLUME \% in entity

7. mean VOLUME \% in entity

8. mean VOLUME \% in entity

9. mean VOLUME \% in entity

10. mean VOLUME \% in entity

1.5 is $\quad 2.95 \%$ of the AREA of the AU

is $\quad 0.01 \%$ of the AREA of the AU

is $\%$ of the AREA of the AU

is $96.88 \%$ of the AREA of the AU 98.33

is $0.17 \%$ of the AREA of the AU

is $\%$ of the AREA of the AU

is $\%$ of the AREA of the AU

is $\%$ of the AREA of the AU

is $\%$ of the AREA of the AU

is $\%$ of the AREA of the AU 


\section{ALLOCATIONS OF POTENTIAL ADDITIONS TO RESERVES TO GENERAL LAND OWNERSHIPS} (continued)

11.

mean VOLUME \% in entity

12.

mean VOLUME \% in entity

13.

mean VOLUME \% in entity

14

mean VOLUME \% in entity

15.

mean VOLUME \% in entity

16.

mean VOLUME \% in entity

17.

mean VOLUME \% in entity

18.

mean VOLUME \% in entity

19. mean VOLUME \% in entity

20. mean VOLUME \% in entity is $\%$ of the AREA of the AU

is $\%$ of the AREA of the AU

is $\%$ of the AREA of the AU

is $\%$ of the AREA of the AU

is $\%$ of the AREA of the AU

is $\%$ of the AREA of the AU

is $\%$ of the AREA of the AU

is $\%$ of the AREA of the AU

is $\%$ of the AREA of the AU

is $\%$ of the AREA of the AU 


\section{ALLOCATIONS OF POTENTIAL ADDITIONS TO RESERVES TO FEDERAL LAND SUBDIVISIONS Surface Allocations}

1. Bureau of Land Management (BLM) mean VOLUME \% in entity

2. BLM Wilderness Areas (BLMW) mean VOLUME \% in entity

3. BLM Roadless Areas (BLMR) mean VOLUME \% in entity

4. National Park Service (NPS) mean VOLUME \% in entity

5. NPS Wilderness Areas (NPSW) mean VOLUME \% in entity

6. NPS Protected Withdrawals (NPSP) mean VOLUME \% in entity

7. US Forest Service (FS) mean VOLUME \% in entity 0.5

8. USFS Wilderness Areas (FSW) mean VOLUME \% in entity

9. USFS Roadless Areas (FSR) mean VOLUME \% in entity

10. USFS Protected Withdrawals (FSP) mean VOLUME \% in entity is $\%$ of the AREA of the AU

is $\%$ of the AREA of the AU

is $\%$ of the AREA of the AU

is $\%$ of the AREA of the AU

is $\%$ of the AREA of the AU

is $\%$ of the AREA of the AU

is $0.31 \%$ of the AREA of the AU

is $\%$ of the AREA of the AU

is $\%$ of the AREA of the AU

is $\%$ of the AREA of the AU 


\section{ALLOCATIONS OF POTENTIAL ADDITIONS TO RESERVES TO FEDERAL LAND SUBDIVISIONS} (continued)

11. US Fish and Wildlife Service (FWS) mean VOLUME \% in entity

12. USFWS Wilderness Areas (FWSW) mean VOLUME \% in entity

13. USFWS Protected Withdrawals (FWSP) mean VOLUME \% in entity

14. Wilderness Study Areas (WS) mean VOLUME \% in entity

15. Department of Energy (DOE) mean VOLUME \% in entity

16. Department of Defense (DOD) mean VOLUME \% in entity

17. Bureau of Reclamation (BOR) mean VOLUME \% in entity

18. Tennessee Valley Authority (TVA) mean VOLUME \% in entity

19. Other Federal mean VOLUME \% in entity

20. mean VOLUME \% in entity is $\%$ of the AREA of the AU

is $\%$ of the AREA of the AU

is $\%$ of the AREA of the AU

is $\%$ of the AREA of the AU

is $\%$ of the AREA of the AU

is 2.63 $\%$ of the AREA of the AU 1

is $\%$ of the AREA of the AU

is $\%$ of the AREA of the AU

is $\%$ of the AREA of the AU

is $\%$ of the AREA of the AU 


\section{ALLOCATIONS OF POTENTIAL ADDITIONS TO RESERVES TO ECOSYSTEMS Surface Allocations}

1. Blackland Prairies (BLPR) mean VOLUME \% in entity 0.00

2. Cross Timbers and Prairie (CRTP) mean VOLUME \% in entity 95.00

3. Edwards Plateau (EDPT) mean VOLUME \% in entity 5.00

4. mean VOLUME \% in entity

5. mean VOLUME \% in entity

6. mean VOLUME \% in entity

7. mean VOLUME \% in entity

8. mean VOLUME \% in entity

9. mean VOLUME \% in entity

10. mean VOLUME \% in entity is

$0.17 \%$ of the AREA of the AU

is $83.85 \%$ of the AREA of the AU

is $15.99 \%$ of the AREA of the AU

is $\%$ of the AREA of the AU

is $\%$ of the AREA of the AU

is $\%$ of the AREA of the AU

is $\%$ of the AREA of the AU

is $\%$ of the AREA of the AU

is $\%$ of the AREA of the AU

is $\%$ of the AREA of the AU 


\section{ALLOCATIONS OF POTENTIAL ADDITIONS TO RESERVES TO ECOSYSTEMS}

(continued)

11.

mean VOLUME \% in entity

12.

mean VOLUME \% in entity

13.

mean VOLUME \% in entity

14.

mean VOLUME \% in entity

15.

mean VOLUME \% in entity

16.

mean VOLUME \% in entity

17.

mean VOLUME \% in entity

18.

mean VOLUME \% in entity

19.

mean VOLUME \% in entity

20.

mean VOLUME \% in entity is $\%$ of the AREA of the AU

is $\%$ of the AREA of the AU

is $\%$ of the AREA of the AU

is $\%$ of the AREA of the AU

is $\%$ of the AREA of the AU

is $\%$ of the AREA of the AU

is $\%$ of the AREA of the AU

is $\%$ of the AREA of the AU

is $\%$ of the AREA of the AU

is $\%$ of the AREA of the AU 
Table 2. (following 13 pages) Input parameters for the Barnett Mixed Continuous Gas and Oil Assessment Unit (50450162), Bend Arch-Fort Worth Basin Province. [bcfg, billion cubic feet of gas; mmcfg, million cubic feet of gas, cfg, cubic feet of gas; mmbo, million barrels of oil; bo, barrel of oil, bliq, barrel of liquid; bngl, barrel of natural gas liquids; m, meters; AU, assessment unit; EUR, estimated ultimate recovery] 
IDENTIFICATION INFORMATION

Assessment Geologist:

Region:

Province:

Total Petroleum System:

Assessment Unit:

Based on Data as of:

Notes from Assessor:
K.R. Marra

North America

Bend Arch-Fort Worth Basin

Barnett-Paleozoic

Barnett Mixed Continuous Gas and Oil

IHS (2015)
Date:

Number:

Number:

Number:

Number:
$9 / 2 / 2015$

5

5045

504501

50450162

\section{CHARACTERISTICS OF ASSESSMENT UNIT}

Assessment-unit type:

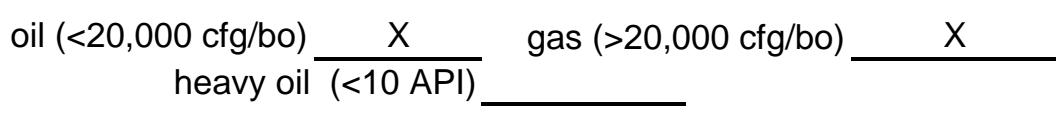

Well type:

vertical horizontal

Major reservoir type (Choose one.):

shale $\mathrm{x}$

low-permeability clastics low-permeability carbonates diatomite

Minimum EUR per well $0.002 \mathrm{MMI}$ (mmbo for oil $\mathrm{AU}$; bcfg for gas $\mathrm{AU}$ )

Number of tested wells: $\quad 3448$

Number of tested wells with EUR > minimum: 2350

Historic success ratio, tested wells (\%)

68

\section{Assessment-Unit Probability:}

What is the probability that at least one well within the $A U$ will have production capacity of at least the minimum EUR?

\section{NUMBER OF UNDRILLED WELLS WITH POTENTIAL FOR ADDITIONS TO RESERVES}

1. Productive area of accumulation (acres): (triangular)
calculated mean $2,019,000$
minimum $1,700,000$
mode $2,057,000$
maximum $\quad 2,300,000$

2. Uncertainty about average drainage area of wells (acres): (triangular)
calculated mean
100
minimum
60
mode
100
maximum

140

3. Percentage of total assessment-unit area that is untested (\%): (triangular)
calculated mean
84
minimum
75

mode

85

maximum

92

4. Percentage of untested wells that are oil wells (\%): (triangular)

$$
\text { calculated mean }
$$

60

minimum

40

mode

65

maximum

75 


\section{ESTIMATED ULTIMATE RECOVERY (EUR) PER WELL}

\section{OIL WELLS}

5a. Future success ratio (\%): (triangular)

calculated mean

47

minimum

30

mode

45

maximum

65

5b. Uncertainty about average EUR (mmbo for oil): (shifted truncated lognormal)

calculated mean

0.036

minimum

0.02

median

0.035

maximum

0.05

\section{GAS WELLS}

6a. Future success ratio (\%): (triangular)

calculated mean

47

minimum

30

mode

45

maximum

65

6b. Uncertainty about average EUR (bcfg for gas): (shifted truncated lognormal)

calculated mean

1.017

minimum

0.5

median

1

maximum

1.5

\section{UNCERTAINTY ABOUT AVERAGE COPRODUCT RATIOS FOR UNTESTED WELLS}

(triangular)

Oil assessment unit:

Gas/oil ratio (cfg/bo)

$\mathrm{NGL} / \mathrm{gas}$ ratio (bngl/mmcfg)

\begin{tabular}{c}
$\begin{array}{c}\text { minimum } \\
7500\end{array}$ \\
\hline 15
\end{tabular}

\begin{tabular}{c}
$\begin{array}{c}\text { mode } \\
8400\end{array}$ \\
\hline 30 \\
\hline
\end{tabular}

maximum

8600

Gas assessment unit:

Liquids/gas ratio (bliq/mmcfg)

15

22 


\section{SELECTED ANCILLARY DATA FOR UNTESTED WELLS}

(no specified distribution type)

Oil wells:

API gravity of oil (degrees)

Sulfur content of oil (\%)

Depth $(m)$ of water (if applicable)

Drilling depth $(\mathrm{m})$

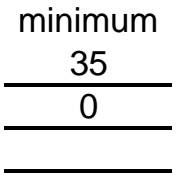

minimum

1100

F75

75

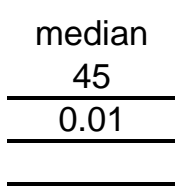

median

1900 maximum

55

0.1

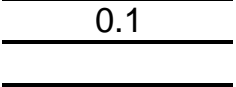

maximum

3050

Gas wells:

Inert-gas content (\%)

$\mathrm{CO}_{2}$ content (\%)

Hydrogen sulfide content (\%)

Heating value (BTU)

Depth $(\mathrm{m})$ of water (if applicable)

Drilling depth $(m)$

\begin{tabular}{|c|c|c|c|c|}
\hline $\begin{array}{c}\text { minimum } \\
0.50\end{array}$ & & $\begin{array}{c}\text { median } \\
2.50\end{array}$ & & $\begin{array}{c}\text { maximum } \\
20.00\end{array}$ \\
\hline 0.10 & & 1.00 & & 5.00 \\
\hline 0.00 & & 0.00 & & 0.00 \\
\hline $\begin{array}{c}\text { minimum } \\
1100\end{array}$ & F75 & $\begin{array}{c}\text { median } \\
1900\end{array}$ & F25 & $\begin{array}{c}\text { maximum } \\
3050\end{array}$ \\
\hline
\end{tabular}

Completion practices:

1. Typical well-completion practices (conventional, open hole, open cavity, other)

2. Fraction of wells drilled that are typically stimulated

3. Predominant type of stimulation (none, frac, acid, other)

4. Historic fraction of wells drilled that are horizontal

\begin{tabular}{c} 
conv \\
\hline 1 \\
\hline frac \\
\hline 0.66 \\
\hline
\end{tabular}




\section{ALLOCATIONS OF POTENTIAL ADDITIONS TO RESERVES TO STATES Surface Allocations}

1. Texas

$\begin{array}{ll}\text { Onshore: } & \frac{100.00}{100.00} \text { area } \% \text { of the } A U \\ \text { mean volume } \% \text { of the } A U & \text { affshore: } \quad \begin{array}{l}\text { area } \% \text { of the } A U \\ \text { mean volume } \% \text { of the } A U\end{array}\end{array}$

2.

Onshore: area $\%$ of the $\mathrm{AU}$ mean volume $\%$ of the $\mathrm{AU}$

Offshore: area $\%$ of the $\mathrm{AU}$ mean volume $\%$ of the $\mathrm{AU}$

3.

Onshore: area $\%$ of the $\mathrm{AU}$ mean volume $\%$ of the $A U$

Offshore: area \% of the $\mathrm{AU}$ mean volume $\%$ of the $A U$

4.

Onshore: area \% of the $\mathrm{AU}$ mean volume $\%$ of the $\mathrm{AU}$

Offshore: area $\%$ of the $\mathrm{AU}$ mean volume $\%$ of the $A U$

5.

Onshore: area $\%$ of the $\mathrm{AU}$ mean volume $\%$ of the $A U$

Offshore: area $\%$ of the $\mathrm{AU}$ mean volume $\%$ of the $A U$ 


\section{ALLOCATIONS OF POTENTIAL ADDITIONS TO RESERVES TO STATES} (continued)

6. area $\%$ of the $\mathrm{AU}$ mean volume $\%$ of the $A U$

Offshore: area $\%$ of the $\mathrm{AU}$ mean volume $\%$ of the $A U$

7.

Onshore: area $\%$ of the $\mathrm{AU}$ mean volume $\%$ of the $A U$

Offshore: area \% of the $\mathrm{AU}$ mean volume $\%$ of the $A U$

8.

Onshore: area $\%$ of the $\mathrm{AU}$ mean volume $\%$ of the $A U$

Offshore: area $\%$ of the $\mathrm{AU}$ mean volume $\%$ of the $\mathrm{AU}$

9.

Onshore: area \% of the $\mathrm{AU}$ mean volume $\%$ of the $A U$

Offshore: area $\%$ of the $\mathrm{AU}$ mean volume $\%$ of the $A U$

10.

Onshore: area $\%$ of the $\mathrm{AU}$ mean volume $\%$ of the $A U$

Offshore: area \% of the $\mathrm{AU}$ mean volume $\%$ of the $A U$ 


\section{ALLOCATIONS OF POTENTIAL ADDITIONS TO RESERVES TO PROVINCES Surface Allocations}

1. Number: 5045

Onshore:

Offshore:

2. Number:

3. Number:

4. Number:

5. Number:

Onshore:

Offshore:

Onshore:

Offshore:

Onshore:

Offshore:
Name: Bend Arch-Fort Worth Basin

$\frac{100.00}{100.00}$ area $\%$ of the $\mathrm{AU}$
mean volume $\%$ of the $\mathrm{AU}$
area $\%$ of the $\mathrm{AU}$
mean volume $\%$ of the $\mathrm{AU}$

Name:

Name:

area $\%$ of the $\mathrm{AU}$
mean volume $\%$ of the $\mathrm{AU}$
area $\%$ of the $\mathrm{AU}$
mean volume $\%$ of the $\mathrm{AU}$

area $\%$ of the $\mathrm{AU}$

mean volume $\%$ of the $A U$

area \% of the $\mathrm{AU}$

mean volume $\%$ of the $A U$

Name:

area $\%$ of the $\mathrm{AU}$

mean volume $\%$ of the $A U$

area $\%$ of the $\mathrm{AU}$

mean volume $\%$ of the $A U$

Name:

area $\%$ of the $\mathrm{AU}$

mean volume $\%$ of the $A U$

Offshore:

area $\%$ of the $\mathrm{AU}$

mean volume $\%$ of the $A U$ 


\section{ALLOCATIONS OF POTENTIAL ADDITIONS TO RESERVES TO PROVINCES}

(continued)

6. Number:

Name:

Onshore:

Offshore:

area $\%$ of the $\mathrm{AU}$

mean volume $\%$ of the $\mathrm{AU}$

area $\%$ of the $\mathrm{AU}$

mean volume $\%$ of the $\mathrm{AU}$

7. Number:

Name:

Onshore:

Offshore:

area $\%$ of the $\mathrm{AU}$

mean volume $\%$ of the $\mathrm{AU}$

area $\%$ of the $\mathrm{AU}$

mean volume $\%$ of the $\mathrm{AU}$

8. Number:

Name:

Onshore:

area $\%$ of the $\mathrm{AU}$

mean volume $\%$ of the $A U$

Offshore:

area $\%$ of the $\mathrm{AU}$

mean volume $\%$ of the $A U$

9. Number:

Name:

Onshore:

area \% of the $\mathrm{AU}$

mean volume $\%$ of the $A U$

Offshore:

area $\%$ of the $\mathrm{AU}$

mean volume $\%$ of the $A U$

10. Number:

Name:

Onshore:

area $\%$ of the $\mathrm{AU}$

mean volume $\%$ of the $A U$

Offshore:

area \% of the $\mathrm{AU}$

mean volume $\%$ of the $A U$ 


\section{ALLOCATIONS OF POTENTIAL ADDITIONS TO RESERVES TO GENERAL LAND OWNERSHIPS Surface Allocations}

1. Federal Lands

mean VOLUME \% in entity

2. Private Lands

mean VOLUME \% in entity

3. Tribal Lands

mean VOLUME \% in entity

4. Other Lands

mean VOLUME \% in entity

5. Texas State Lands

mean VOLUME \% in entity

0.04

6.

mean VOLUME \% in entity

7.

mean VOLUME \% in entity

8.

mean VOLUME \% in entity

9.

mean VOLUME \% in entity

10.

mean VOLUME \% in entity

10

89.96 is

$4.64 \%$ of the AREA of the AU

is

$\%$ of the AREA of the AU

is

$\%$ of the AREA of the AU

is

$95.32 \%$ of the AREA of the AU

is $0.04 \%$ of the AREA of the AU

is $\%$ of the AREA of the AU

is $\%$ of the AREA of the AU

is $\%$ of the AREA of the AU

is $\%$ of the AREA of the AU

is $\%$ of the AREA of the AU 


\section{ALLOCATIONS OF POTENTIAL ADDITIONS TO RESERVES TO GENERAL LAND OWNERSHIPS} (continued)

11.

mean VOLUME \% in entity

12.

mean VOLUME \% in entity

13.

mean VOLUME \% in entity

14.

mean VOLUME \% in entity

15.

mean VOLUME \% in entity

16.

mean VOLUME \% in entity

17.

mean VOLUME \% in entity

18.

mean VOLUME \% in entity

19.

mean VOLUME \% in entity

20.

mean VOLUME \% in entity is

$\%$ of the AREA of the AU

is

$\%$ of the AREA of the AU

$\%$ of the AREA of the AU

$\%$ of the AREA of the AU

$\%$ of the AREA of the AU

$\%$ of the AREA of the AU

is $\%$ of the AREA of the AU

is $\%$ of the AREA of the AU

is $\%$ of the AREA of the AU

is $\%$ of the AREA of the AU 


\section{ALLOCATIONS OF POTENTIAL ADDITIONS TO RESERVES TO FEDERAL LAND SUBDIVISIONS Surface Allocations}

1. Bureau of Land Management (BLM) mean VOLUME \% in entity

2. BLM Wilderness Areas (BLMW) mean VOLUME \% in entity

3. BLM Roadless Areas (BLMR) mean VOLUME \% in entity

4. National Park Service (NPS) mean VOLUME \% in entity

5. NPS Wilderness Areas (NPSW) mean VOLUME \% in entity

6. NPS Protected Withdrawals (NPSP) mean VOLUME \% in entity

7. US Forest Service (FS) mean VOLUME \% in entity 10

8. USFS Wilderness Areas (FSW) mean VOLUME \% in entity

9. USFS Roadless Areas (FSR) mean VOLUME \% in entity

10. USFS Protected Withdrawals (FSP) mean VOLUME \% in entity is $\%$ of the AREA of the AU

is $\%$ of the AREA of the AU

is $\%$ of the AREA of the AU

is $\%$ of the AREA of the AU

is $\%$ of the AREA of the AU

is $\%$ of the AREA of the AU

is $4.64 \%$ of the AREA of the AU

is $\%$ of the AREA of the AU

is $\%$ of the AREA of the AU

is $\%$ of the AREA of the AU 


\section{ALLOCATIONS OF POTENTIAL ADDITIONS TO RESERVES TO FEDERAL LAND SUBDIVISIONS} (continued)

11. US Fish and Wildlife Service (FWS) mean VOLUME \% in entity

12. USFWS Wilderness Areas (FWSW) mean VOLUME \% in entity

13. USFWS Protected Withdrawals (FWSP) mean VOLUME \% in entity

14. Wilderness Study Areas (WS) mean VOLUME \% in entity

15. Department of Energy (DOE) mean VOLUME $\%$ in entity

16. Department of Defense (DOD) mean VOLUME \% in entity

17. Bureau of Reclamation (BOR) mean VOLUME \% in entity

18. Tennessee Valley Authority (TVA) mean VOLUME \% in entity

19. Other Federal mean VOLUME \% in entity

20. mean VOLUME \% in entity is $\%$ of the AREA of the AU

is $\%$ of the AREA of the AU

is $\%$ of the AREA of the AU

is $\%$ of the AREA of the AU

is $\%$ of the AREA of the AU

is $0.00 \quad \%$ of the AREA of the AU

is $\%$ of the AREA of the AU

is $\%$ of the AREA of the AU

is $\%$ of the AREA of the AU

is $\%$ of the AREA of the AU 


\section{ALLOCATIONS OF POTENTIAL ADDITIONS TO RESERVES TO ECOSYSTEMS Surface Allocations}

1. Cross Timbers and Prairie (CRTP) mean VOLUME \% in entity

2. Rolling Plains (RLPL) mean VOLUME \% in entity 3

3. mean VOLUME \% in entity

4. mean VOLUME \% in entity

5. mean VOLUME \% in entity

6. mean VOLUME \% in entity

7. mean VOLUME \% in entity

8. mean VOLUME \% in entity

9. mean VOLUME \% in entity

10. mean VOLUME \% in entity is $\quad 84.44 \quad \%$ of the AREA of the AU

is $15.56 \%$ of the AREA of the AU

is $\%$ of the AREA of the AU

is $\%$ of the AREA of the AU

is $\%$ of the AREA of the AU

is $\%$ of the AREA of the AU

is $\%$ of the AREA of the AU

is $\%$ of the AREA of the AU

is $\%$ of the AREA of the AU is $\%$ of the AREA of the AU 


\section{ALLOCATIONS OF POTENTIAL ADDITIONS TO RESERVES TO ECOSYSTEMS}

(continued)

11.

mean VOLUME \% in entity

12.

mean VOLUME \% in entity

13.

mean VOLUME \% in entity

14.

mean VOLUME \% in entity

15.

mean VOLUME \% in entity

16.

mean VOLUME \% in entity

17.

mean VOLUME \% in entity

18.

mean VOLUME \% in entity

19.

mean VOLUME \% in entity

20.

mean VOLUME \% in entity is

$\%$ of the AREA of the AU

is

$\%$ of the AREA of the AU

$\%$ of the AREA of the AU

$\%$ of the AREA of the AU

$\%$ of the AREA of the AU

$\%$ of the AREA of the AU

is $\%$ of the AREA of the AU

is $\%$ of the AREA of the AU

is $\%$ of the AREA of the AU

is $\%$ of the AREA of the AU 